\title{
Journal of Specific and common antigenic determinants Clinical Microbiology of Candida albicans isolates detected by monoclonal antibody.
}

L Polonelli and G Morace

J. Clin. Microbiol. 1986, 23(2):366.

Updated information and services can be found at:

http://jcm.asm.org/content/23/2/366

\section{These include:}

CONTENT ALERTS Receive: RSS Feeds, eTOCs, free email alerts (when new articles cite this article), more» 


\title{
Specific and Common Antigenic Determinants of Candida albicans Isolates Detected by Monoclonal Antibody
}

\author{
LUCIANO POLONELLI* AND GIULIA MORACE \\ Istituto di Microbiologia, Facoltà di Medicina e Chirurgia “A. Gemelli," Università Cattolica del Sacro Cuore, 00168 \\ Rome, Italy
}

Received 26 August 1985/Accepted 28 October 1985

\begin{abstract}
We isolated a hybridoma cell line which produced monoclonal antibody to one determinant of an exoantigen of Candida albicans. The immunoglobulin $G$ antibody product was characterized by using a Western blot technique and was used for a serological analysis of numerous homologous and heterologous yeast isolates. Based on specific immunologic determinants, $C$. albicans strains were identified and clustered into five groups. The monoclonal antibodies were effective reagents for identifying and serotyping our $C$. albicans isolates; they have potential application in the epidemiology of yeast infections.
\end{abstract}

Monoclonal antibodies can be invaluable tools for studying the properties of large groups of microorganisms, including fungi. The most common use of monoclonal antibodies is in the development of immunodiagnostic tests for detecting infection by specific organisms.

Previous reports of immunoidentification of pathogenic fungi (4) and yeasts (7) performed with polyvalent antisera prompted us to evaluate the potential use of monoclonal antibodies for identification and serotyping of the pathogenic yeast Candida albicans. The question which we asked was whether monoclonal antibodies, because of their specificity, could be more useful than polyvalent antisera.

In this paper we describe the production and characterization of a monoclonal antibody to Candida albicans soluble antigen for use in the Western blot technique.

\section{MATERIALS AND METHODS}

Cultures. The yeast isolates used were from our collection or were kindly furnished by the Division of Mycotic Diseases, Centers for Disease Control, Atlanta, Ga.; Centraalbureau voor Schimmelcultures, Baarn, The Netherlands; and Istituto Superiore di Sanità, Rome, Italy (Table 1).

Reference antigens. All of the yeast culture antigens were prepared by the following procedure. Yeast isolates were cultured on Sabouraud dextrose agar slants at $25^{\circ} \mathrm{C}$ for $48 \mathrm{~h}$. An 8-ml portion of a Merthiolate-water $(1: 5,000)$ solution was added to each culture, and the cultures were allowed to stand overnight at room temperature. After this, a 5-ml portion of each solution was filtered and lyophilized. The product was suspended in $0.1 \mathrm{ml}$ of sterile water $(50 \times$ concentrated) and adjusted to a final concentration of 2,500 $\mu \mathrm{g}$ of protein per ml, as determined by the method of Lowry et al. (3).

Mouse immunization. Candida albicans CDC B385 antigen was the antigen used for mouse immunizations. BALB/c mice were immunized according to the following schedule: $0.1 \mathrm{ml}$ of the reference antigen, containing $2,500 \mu \mathrm{g}$ of protein per $\mathrm{ml}$ and $550 \mu \mathrm{g}$ of carbohydrate per $\mathrm{ml}(6)$, was mixed with $0.1 \mathrm{ml}$ of incomplete Freund adjuvant and injected intraperitoneally once a week for 1 month; an intraperitoneal booster injection $(0.1 \mathrm{ml}$ of the soluble reference antigen) was given 3 days before the mice were killed to obtain spleen cells for fusion experiments.

\footnotetext{
* Corresponding author.
}

Cells and media. Cell line NS1, which was kindly provided by Lenore Pereira, Virology Laboratory, Department of Health, Berkeley, Calif., was the myeloma cell line used in this study. The myeloma cell line and the hybrids derived from its fusion with BALB/c mouse spleen cells were grown in RPMI 1640 medium (GIBCO Laboratories, Grand Island, N.Y.) supplemented with $20 \%$ fetal bovine serum (lot 12103059; GIBCO).

Hybridization and selection of antibody-producing hybrids. The hybridization procedure, the selection of hybrids which produced the desired monoclonal antibodies, and the check of the monoclonality of the antibodies were carried out as previously described $(1,5)$. The immunoglobulin class was determined by immunodiffusion with rabbit-specific antisera (Miles Laboratories, Inc., Elkhart, Ind.).

Western blot of yeast proteins. A $5-\mathrm{ml}$ portion of yeast antigens was lyophilized and then added to $150 \mu \mathrm{l}$ of a solution $(150 \mu \mathrm{g} / \mathrm{ml})$ of molecules having known molecular weights (RNase A [molecular weight, 13,700], chymotrypsinogen $[25,000]$, ovalbumin $[43,000])$; this preparation was dissolved in $0.5 \mathrm{ml}$ of disruptor buffer, which contained $1 \mathrm{M}$ Tris ( $\mathrm{pH} \mathrm{7.0),60 \%} \mathrm{(wt/vol)} \mathrm{sucrose,} 2 \%(\mathrm{wt} / \mathrm{vol})$ sodium dodecyl sulfate, $5 \%$ (wt/vol) $\beta$-mercaptoethanol, and $0.02 \%$ saturated bromphenol blue solution as a tracing dye. The solution was boiled for $5 \mathrm{~min}$ before loading onto sodium dodecyl sulfate-10\% polyacrylamide gels and subsequent electrophoresis (15 $\mathrm{mA}$ for $18 \mathrm{~h}$ ) in a vertical gel system (Bethesda Research Laboratories, Inc., Gaithersburg, Md.). Electrophoretic transfer of yeast peptides to nitrocellulose paper $(0.45 \mu \mathrm{m}$; Schleicher \& Schuell, Inc., Keene, N.H.) was performed by a modification of the Western blot method of Towbin et al. (8). Polyacrylamide gels were equilibrated for 10 to $15 \mathrm{~min}$ in transfer buffer $(25 \mathrm{mM}$ Tris base, $192 \mathrm{mM}$ glycine, $20 \%$ methanol) and then placed on a wet sponge and filter paper (Whatman no. 1), and sheets of nitrocellulose were layered over the gels. A sandwich was composed by adding a second piece of filter paper and sponge. The sandwich was placed between supports into a Trans Blot cell (Bio-Rad Laboratories, Richmond, Calif.) with the nitrocellulose sheet facing the anode. The chamber was filled with the transfer buffer, and $60 \mathrm{~V}$ was applied for $90 \mathrm{~min}$ at room temperature. After this, the transfer buffer was substituted, and the voltage was applied for another $90 \mathrm{~min}$.

Detection of monoclonal antibodies to polypeptides trans- 
TABLE 1. Western blot analysis of yeast isolates with Candida albicans monoclonal antibody UCSC 1

\begin{tabular}{|c|c|c|}
\hline Species & Strain $^{a}$ & $\begin{array}{c}\text { Mol wt }\left(10^{3}\right) \text { of } \\
\text { bands }\end{array}$ \\
\hline $\begin{array}{l}\text { Blastoschizomyces } \\
\text { capitatus }\end{array}$ & UCSC 0 & $19,27,33,45$ \\
\hline Candida albicans & $\begin{array}{l}\text { CDC B385 } \\
\text { CBS } 5983 \\
\text { CBS } 103 \\
\text { CBS } 9931 \\
\text { CDC B612 } \\
\text { CDC B1073 } \\
\text { UCSC 0 } \\
\text { UCSC } 10 \\
\text { UCSC } 66 \\
\text { UCSC } 101\end{array}$ & $\begin{array}{l}12,20,35 \\
12,54 \\
12 \\
12,50 \\
12,35 \\
12 \\
12 \\
12 \\
12 \\
12\end{array}$ \\
\hline Candida quilliermondii & CBS 566 & $25,45,78$ \\
\hline Candida krusei & CBS 573 & $25,48,78$ \\
\hline Candida parapsilosis & CBS 604 & 37,66 \\
\hline $\begin{array}{l}\text { Candida pseudotropicalis } \\
\text { Candida tropicalis }\end{array}$ & $\begin{array}{l}\text { CBS } 607 \\
\text { CBS } 94\end{array}$ & $\begin{array}{l}25,45,70 \\
20,44,60\end{array}$ \\
\hline $\begin{array}{l}\text { Cryptococcus } \\
\text { neoformans }\end{array}$ & CDC B551 & $20,45,68$ \\
\hline Malassezia furfur & ISS F1 & $13,24,45,80$ \\
\hline $\begin{array}{l}\text { Malassezia pachy } \\
\text { dermatis }\end{array}$ & ISS P1 & $21,25,100$ \\
\hline Rhodotorula glutinis & UCSC 0 & 21 \\
\hline $\begin{array}{l}\text { Saccharomyces } \\
\text { cerevisiae }\end{array}$ & CDC B2210 & $34,42,58,78,92$ \\
\hline Torulopsis glabrata & CBS 138 & 17 \\
\hline
\end{tabular}

a CDC, Centers for Disease Control, Atlanta, Ga.; UCSC, Università Cattolica del Sacro Cuore, Rome, Italy; CBS, Centraalbureau voor Schimmelcultures, Baarn, The Netherlands; ISS, Istituto Superiore di Sanità, Rome, Italy.

ferred to nitrocellulose. A sheet of nitrocellulose paper to which peptides had been transferred was cut into strips for reaction with monoclonal antibodies. The nitrocellulose strips were incubated for $30 \mathrm{~min}$ at room temperature in phosphate-buffered saline (PBS) containing $5 \%$ (vol/vol) horse serum. Each nitrocellulose strip was then incubated at $37^{\circ} \mathrm{C}$ for $30 \mathrm{~min}$ in a shaker with $0.2 \mathrm{ml}$ of hybridoma culture fluid diluted 1:10 in PBS containing 5\% horse serum. The strips were then washed twice in PBS to remove unbound antibodies. To detect bound monoclonal antibodies, each strip was then incubated in $3 \mathrm{ml}$ of PBS containing 5\% horse serum for $30 \mathrm{~min}$ at room temperature in a shaker. Horseradish peroxidase-conjugated rabbit anti-mouse immunoglobulin G (Miles Laboratories) was diluted 1:500 in PBS containing $5 \%$ horse serum, and $3 \mathrm{ml}$ was added to each strip for $30 \mathrm{~min}$ at $37^{\circ} \mathrm{C}$ in a shaker. After extensive washing in PBS, the strips were developed in $100 \mathrm{ml}$ of water with $1 \mathrm{ml}$ of a $1 \%$ solution of 4-chloro-1-naphthol (Sigma Chemical Co., St. Louis, Mo.) in methanol. Hydrogen peroxide was added to a final concentration of $0.01 \%$. As bluish bands appeared, the strips were collected and dried. A few strips from each gel were differentially fixed and stained with $0.1 \%$ Coomassie blue for visualizing the molecular weight markers and controlling the efficiency of transfer. Plotting the migration patterns permitted accurate evaluation of the molecular weights of the antigenic determinants in the strips that reacted with the monoclonal antibodies (1).

\section{RESULTS}

Nine hybrids producing monoclonal antibodies belonging to the immunoglobulin $G$ class were produced by fusion.
When the Candida albicans reference antigen was electrophoretically separated in denaturing gels and then immobilized on nitrocellulose strips, we did not detect any diversity in the monoclonal antibodies to yeast proteins. Candida albicans monoclonal antibody UCSC 1 was selected for its avidity properties. When the antigens of all of the yeast isolates studied were tested by the Western blot technique, Candida albicans monoclonal antibody UCSC 1 displayed a potential to discriminate among various isolates (Fig. 1).

All of the Candida albicans strains had a species-specific determinant located at a molecular weight of 12,000. Candida albicans monoclonal antibody UCSC 1 was used to characterize five different presumptive serotypes within the species which reacted in different isolates with other antigenic determinants having different molecular weights. Cross-reactions occurred with other yeast species having different molecular weights (Table 1). Interestingly, the antigenic determinant with the closest molecular weight was detected in the Malassezia furfur isolate.

\section{DISCUSSION}

Traditionally, identification of Candida albicans isolates has been based on biochemical and morphological criteria. More recently, serological methods have been used for classification of the Candida species and their serotypes (7). However, serological methods may prevent autoagglutination, require combined biological tests, and recognize only the two serotypes (serotypes A and B) generally accepted within the species Candida albicans (2).

For this study, we had to make a preliminary choice (on grounds other than questionable immunization procedures) between using intact cells and using soluble antigens as immunogens. Because this study was intended to be directed to immunoidentification of opportunistic yeasts, we used a soluble antigen, namely, a reference exoantigen, since this type of antigen has previously been highly effective for the

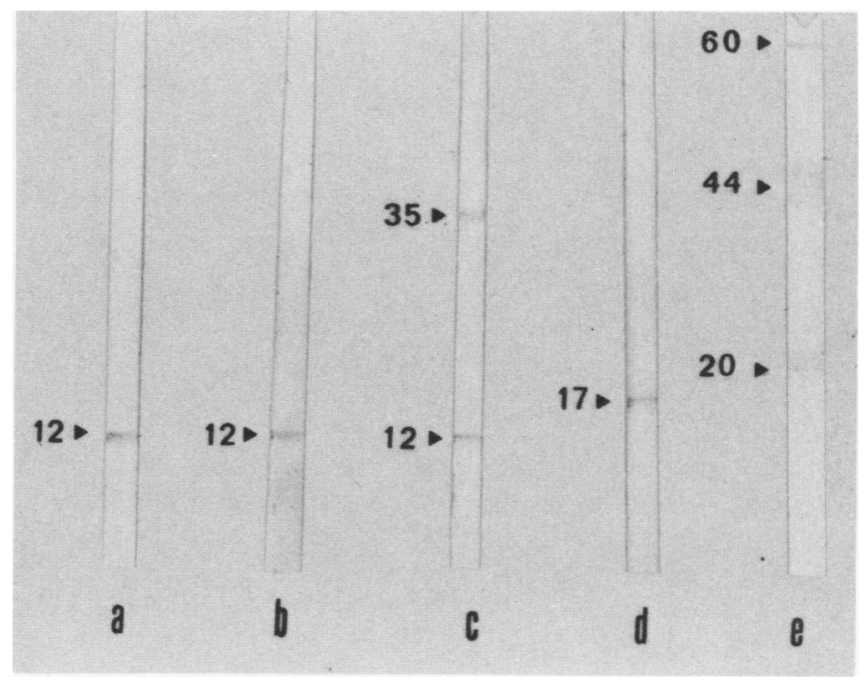

FIG. 1. Western blot analysis of yeast isolates with Candida albicans monoclonal antibody UCSC 1 . Lane a, Candida albicans CDC B1073; lane b, Candida albicans UCSC 66; lane c, Candida albicans CDC B612; lane d, Torulopsis glabrata CBS 138; lane e, Candida tropicalis CBS 94 exoantigens. The molecular weights $\left(\times 10^{3}\right)$ of bands are indicated to the left of each lane. 
rapid and specific identification of mycelial cultures of pathogenic fungi (4).

Using a monoclonal antibody to a soluble antigen of Candida albicans, we demonstrated the presence of 12,000 dalton antigenic determinant that was shared by the type strain and by all of the Candida albicans isolates tested. No yeast isolate belonging to any other species investigated had an identical antigenic determinant. The similarity in molecular weight between the 12,000-dalton antigenic determinant of Candida albicans strains and the 13,000-dalton determinant of the $M$. furfur isolate examined suggests that there is a common function, but does not pose any diagnostic problem; thus, monoclonal antibodies can be readily adapted for identification purposes.

Furthermore, we found that such antigenic determinants may be expressed at different molecular weights in different strains within the species, since they are located on different molecules. Based on specific immunological determinants, the Candida albicans strains were clustered in five presumptive serotypes.

Additional experiments will be needed to determine whether the antigenically related proteins having different molecular weights are modifications of a common protein or the polymerized states of a protein which was not separated under the denaturing conditions used in this study.

The data presented in this paper show that monoclonal antibodies are powerful reagents for the identification and serotyping of Candida albicans strains. They also have potential application to the epidemiology of yeast infections. We expect that the serotypes are dependent upon the number of selected monoclonal antibodies used for analysis and that additional groupings should emerge as more hybridomas are used.

The poor variability in the responses of monoclonal antibodies to the immunization antigen could be attributed to a dominant immunogenic component. In our institute, work is in progress to achieve partial purification of the exoantigen by using Candida albicans monoclonal antibody UCSC 1 as an immunoadsorbent in affinity chromatography. This procedure should permit us to obtain a purified antigen which is depleted of the relative antigenic determinant. The use of such a purified antigen for mouse immunization should permit the production of different monoclonal antibodies.

\section{ACKNOWLEDGMENTS}

This work was supported by grants from the Ministero della Pubblica Istruzione and the Consiglio Nazionale delle Ricerche (P.F.:CMI contract 84.02040.52).

We are indebted to Libero Ajello, Centers for Disease Control, for his constant interest in our work.

\section{LITERATURE CITED}

1. Braun, D. K., L. Pereira, B. Norrild, and B. Roizman. 1983. Application of denatured, electrophoretically separated, and immobilized lysates of herpes simplex virus-infected cells for detection of monoclonal antibodies and for studies of the properties of viral proteins. J. Virol, 46:103-112.

2. Hasenclever, H. R., and W. O. Mitchell. 1961. Antigenic studies of Candida. I. Observation of two antigenic groups in Candida albicans. J. Bacteriol. 82:570-573.

3. Lowry, O. H., N: J. Rosebrough, A. L. Farr, and R. J. Randall. 1951. Protein measurement with the Folin phenol reagent. J. Biol. Chem. 193:265-275.

4. Polonelli, L., and G. Morace. 1984. Rapid immunoidentification of pathogenic fungi, p. 203-219. In A. Sanna and G. Morace (ed.), New horizons in microbiology. Elsevier Publishers, Amsterdam.

5. Polonelli, L., and G. Morace. 1985. Serological analysis of dermatophyte isolates with monoclonal antibodies produced against Microsporum canis. J. Clin. Microbiol. 21:138-139.

6. Roe, J. H. 1955. The determination of sugar in blood and spinal fluid with antrone reagent. J. Biol. Chem. 212:335.

7. Taguchi, M., M. Tsukiji, and T. Tsuchya. 1979. Rapid identification of yeasts by serological methods. A combined serological and biological method. Sabouraudia 17:185-191.

8. Towbin, H., T. Staehelin, and J. Gordon. 1979. Electrophoretic transfer of proteins from polyacrylamide gels to nitrocellulose sheets: procedure and some applications. Proc. Natl. Acad. Sci. USA 76:4350-4354. 